\title{
KALIMAT INVERSI DENGAN SUBJEK KOMPLEKS DALAM BAHASA INDONESIA RAGAM JURNALISTIK
}

\author{
(Inversion Sentences with Complex Subject \\ in Indonesian Language of Journalistic Variety)
}

\author{
Wagiati \\ Fakultas Ilmu Budaya Universitas Padjadjaran \\ Jalan Ir. Soekarno km 21 Jatinangor Sumedang, Jawa Barat, Indonesia \\ Pos-el: wagiati@unpad.ac.id \\ Duddy Zein \\ Fakultas Ilmu Komunikasi Universitas Padjadjaran \\ Jl. Hegarmanah, Hegarmanah, Jatinangor, Kabupaten Sumedang, Jawa Barat \\ Pos-el : zein@unpad.ac.id
}

(Diterima: 30 Maret 2018 ; Direvisi: 20 Juni ; Disetujui: 22 Juni 2018 )

\begin{abstract}
This research titled "Inversion Sentences with Complex Subjects in Journalistic Style-Indonesian Language." The purposes of this study are (1) to study the construction of predicate and subject construction in inversion sentences with a complex subject, and (2) to study the change of structure of predicate-subject to subject-predicate in inversion sentence with a complex subject. The result of the research shows that sentences inversion with the complex subject is found frequently used in Journalistic Style-Indonesian Language. The form of verbs that become the predicate is generally a passive verb which beginning with \{ter-\} or \{di-\}. The constituents of predicate filler are found in the form of a word, which is verb only and also found in the form of verb + adverbs which forms verbal phrases. The complex subject based on the construction can be whether a phrase or a clause. The structural changes from predicate-subject to subject-predicate in inversion sentences with complex subjects generally depend on the constituents of predicate filler. If the predicate is only a verb, the reversal of the structure from predicate- subject to subject-predicate will form less common sentences. However, if the predicate form is verb + adverbial and creates a verbal phrase, the reversal of the structure from subject-predicate to subject-predicate will form a common sentence.
\end{abstract}

Keywords: inverse sentence, complex subject, journalistic variety

\begin{abstract}
Abstrak
Penelitian ini berjudul "Kalimat Inversi dengan Subjek Kompleks dalam Bahasa Indonesia Ragam Jurnalistik". Tujuan penelitian ini adalah (1) mengkaji konstruksi predikat dan konstruksi subjek pada kalimat inversi dengan subjek kompleks dan (2) mengkaji perubahan struktur dari predikat-subjek menjadi subjek-predikat pada kalimat inversi dengan subjek kompleks. Hasil penelitian menunjukkan bahwa dalam bahasa Indonesia ragam jurnalistik banyak ditemukan kalimat inversi dengan subjek kompleks. Bentuk verba yang menjadi predikat pada umumnya berupa verba pasif berawalan \{ter-\} atau $\{$ di- $\}$. Konstituen pengisi predikatnya ada yang berupa kata, yakni verba saja, dan ada pula yang berupa verba + adverbia dan membentuk frasa verbal. Subjek kompleks berdasarkan konstruksinya dapat berupa frasa dan dapat pula berupa klausa. Perubahan struktur dari predikat-subjek menjadi subjek-predikat pada kalimat inversi dengan subjek kompleks pada umumnya bergantung pada konstituen pengisi predikat. Jika predikat berupa verba saja, pembalikan struktur dari predikat-subjek menjadi subjek-predikat akan menghasilkan kalimat yang kurang lazim. Namun, jika predikat berupa verba + adverbia sehingga membentuk frasa verbal, pembalikan struktur dari predikat-subjek menjadi subjek-predikat akan menghasilkan kalimat yang lazim.
\end{abstract}

Kata-kata Kunci: kalimat inversi , subjek kompleks, ragam jurnalistik 


\section{PENDAHULUAN}

Urutan fungsi dalam kalimat bahasa Indonesia pada umumnya adalah subjekpredikat. Dengan demikian, jika ada urutan predikat-subjek hal ini akan dianggap telah terjadi pembalikan urutan. Hal tersebut didukung oleh pendapat Sugono (1995: 60 - 64) yang menjelaskan bahwa kalimat dasar mempunyai urutan linear subjekpredikat bagi bahasa-bahasa penampil subjek, seperti bahasa Indonesia. Di dalam bahasa Indonesia, urutan subjek-predikat atau subjek-predikat-objek lebih dasar daripada urutan predikat-subjek atau predikat-objek-subjek.

Sejalan dengan pendapat Sugono, Alwi, dkk. (2003:322) menjelaskan bahwa pola umum kalimat dasar bahasa Indonesia dapat dinyatakan seperti pada contoh (1) berikut dengan catatan bahwa unsur objek, pelengkap, dan keterangan yang ditulis dalam tanda kurung itu tidak selalu hadir dan keterangan dapat lebih dari satu.

(1) $\mathrm{S}+\mathrm{P}+(\mathrm{O})+(\mathrm{Pel})+($ Ket $)$

Berdasarkan pola umum kalimat bahasa Indonesia tersebut tampak bahwa urutan fungsi sintaktis kalimat dasar bahasa Indonesia mengikuti pola subjek-predikat. Artinya, dalam kalimat dasar bahasa Indonesia, subjek terletak di depan atau mendahului predikat.

Alwi dkk

(2003:322-323)

menambahkan bahwa apabila konstituen kalimat dasar yang tidak wajib diabaikan, dari pola umum pada (1) di atas dapat diturunkan enam tipe kalimat dasar sebagaimana terlihat pada contoh (2) berikut.

(2) a. Anak-anak / sedang berenang $\mathrm{S} \quad \mathrm{P}$

b. Kami / akan menulis / surat.

$$
\begin{array}{lll}
\mathrm{S} & \mathrm{P} & \mathrm{O}
\end{array}
$$

c. Pak Ali / menjadi / camat .

$$
\text { S P Pel }
$$

d. Mereka / berasal / dari Surabaya.
$\mathrm{S} \quad \mathrm{P} \quad \mathrm{K}$

e. Bu Herni / membelikan / anaknya / $\mathrm{S} \quad \mathrm{P}$ sepeda baru.

Pel

f. Pak Hadi / memasukkan / mobilnya $\begin{array}{lll}\mathrm{S} & \mathrm{P} & \mathrm{O}\end{array}$ / ke garasi.

$\mathrm{K}$

Pada contoh (2) tersebut tampak bahwa berdasarkan urutan fungsi sintaktisnya, pada semua pola kalimat dasar bahasa Indonesia tersebut subjek berada di depan predikat. Itu sebabnya di atas dikemukakan bahwa di dalam bahasa Indonesia, urutan subjek-predikat lebih dasar daripada urutan predikat-subjek.

Namun, berdasarkan penelitian terhadap data, banyak ditemukan kalimat berstruktur predikat-subjek dalam bahasa Indonesia. Perhatikan contoh berikut ini.

(3) a. "Apa / yang kalian bicarakan tadi?" (LB: 97) $\mathrm{P} \quad \mathrm{S}$

b. Tak seorang pun / yang sudah berkuasa rela kehilangan kekuasaannya. (KO) $\mathrm{P}$ $S$

c. Pada pil itu / ada / tulisan besar APC. (LP: 18) $\begin{array}{lll}\mathrm{K} & \mathrm{P} & \mathrm{S}\end{array}$

d. Di papan tulis itu / terpampang / gambar matahari dengan garis-garis sinar berwarna putih putih. (LP: 1819)

$$
\text { K P } \quad \mathrm{S}
$$

Pada keempat kalimat di atas, konstituenkonstituen yang dicetak miring, yaitu secara berturut-turut apa, tak seorang pun, $a d a$, dan terpampang adalah predikat, dan konstituen-konstituen yang mengikutinya secara berturut-turut adalah subjek. Dengan demikian, pada keempat kalimat di atas predikat terletak di depan subjek.

Kalimat dengan susunan predikatsubjek, secara umum, sering disebut sebagai kalimat inversi. Kalimat inversi 
ini, di antaranya, banyak ditemukan dalam bahasa Indonesia ragam jurnalistik, khususnya dalam surat kabar atau majalah. Berdasarkan penelitian terhadap data, kalimat inversi yang terdapat pada surat kabar atau majalah memiliki bermacammacam tipe. Salah satu di antaranya adalah kalimat inversi dengan subjek yang panjang. Perhatikan contoh berikut.

(4) a. Tahun ini pula/terbetik/ sebuah kabar bahwa TNI AD, seperti ditulis TEMPO, justru menginstruksikan kepada seluruh jajarannya di daerah untuk mengajak masyarakat menonton bersama film Pengkhianatan G 30 S PKI. (TO, 2017)

b. Sempat tersiarl kabar isu perselingkuhan yang menjadi penyebab retaknya bahtera rumah tangga Nora Alexandra dan Afiff Alli yang resmi dibina pada 28 September 2016 lalu itu. (KO, 2017)

c. Terjawab sudah// ke mana mantan bek PSM Makassar, Hamka Hamzah, akan melanjutkan kariernya. (KO, 2018)

d. Diberitahukan / kepada seluruh mahasiswa/wi STIKI // bahwa jatuh tempo pembayaran SKS Semester Ganjil 2016/2017 ialah sebagai berikut: Mahasiswa Angkatan $<=2014$ pembayaran 12 SKS tanggal 7 Oktober 2016; Mahasiswa Angkatan 2015 pembayaran Keseluruhan SKS tanggal 7 Oktober 2016. (TO, 2017)

Pada keempat kalimat tersebut konstituen yang dicetak miring adalah predikat, sedangkan konstituen yang mengikutinya adalah subjek, kecuali pada contoh (4.d) predikat diikuti oleh keterangan dulu, baru subjek. Tampak pada keempat kalimat tersebut bahwa predikat terletak pada awal kalimat, kecuali pada kalimat (4.a) kalimat diawali langsung oleh keterangan, baru predikat, lalu subjek. Dengan demikian, keempat kalimat tersebut berstruktur predikat-subjek atau kalimat inversi. Selain memiliki susunan inversi, yang menarik perhatian dari keempat kalimat tersebut adalah subjek keempat kalimat tersebut terdiri atas konstituen yang panjang. Berdasarkan pengamatan terhadap data, subjek yang panjang ini dapat berupa frasa dan dapat pula berupa klausa. Subjek yang terdiri atas konstituen yang panjang ini, selanjutnya, akan disebut subjek kompleks. Kalimat inversi dengan subjek berupa subjek kompleks banyak ditemukan dalam bahasa Indonesia ragam jurnalistik. Karena itulah, objek penelitian ini adalah bahasa Indonesia ragam jurnalistik.

Persoalan kalimat inversi dapat dikaji dari berbagai segi. Penempatan predikat pada awal kalimat, secara analisis wacana, menandakan bahwa predikat mendapat prioritas atau mendapat pemfokusan. Menyoroti kalimat inversi dari segi pemfokusan terhadap predikat, merupakan bagian dari analisis wacana. Akan tetapi, kalimat inversi pun dapat pula disoroti dari segi konstruksinya, baik konstruksi predikat maupun konstruksi subjeknya. Menyoroti kalimat inversi dari segi konstruksi unsur-unsur pengisinya merupakan bagian dari analisis secara sintaktis. Pada penelitian ini kalimat inversi dengan subjek kompleks dikaji secara sintaktis. Secara sintaktis menarik untuk dikaji bagaimana konstruksi predikat dan konstruksi subjek pada kalimat inversi dengan subjek kompleks tersebut. Hal lain yang penting untuk diteliti adalah apakah kalimat-kalimat tersebut dapat diubah strukturnya menjadi subjek-predikat atau tidak. Berdasarkan pertanyaan-pertanyaan tersebut, penelitian ini mengkaji (1) bagaimana konstruksi predikat dan konstruksi subjek pada kalimat inversi dengan subjek kompleks dalam bahasa Indonesia ragam jurnalistik dan (2) bagaimana perubahan struktur dari predikat-subjek menjadi subjek-predikat pada kalimat inversi dengan subjek kompleks. 


\section{METODE PENELITIAN}

Metode yang digunakan dalam penelitian ini adalah metode deskriptif dengan jangkauan waktu bersifat sinkronis. Metode deskriptif bertujuan membuat deskripsi atau gambaran, lukisan secara sistematis, faktual dan akurat mengenai data, sifat-sifat, serta fenomena yang diteliti (Djajasudarma, 1993: 8). Metode ini menyarankan penelitian dilakukan semata-mata berdasarkan fakta yang ada atau fenomena yang memang empiris hidup dalam penutur-penuturnya sehingga hasil yang diharapkan berupa perian bahasa yang berupa potret seperti apa adanya (Sudaryanto, 1992: 62).

Metode dan teknik analisis data yang digunakan dalam penelitian ini adalah metode distribusional. Sudaryanto (1993) menyebutnya dengan metode agih, yaitu metode yang alat penentunya bagian dari bahasa yang bersangkutan itu sendiri. Berkaitan dengan penelitian ini, teknik kajian distribusional yang digunakan adalah teknik balik.

Adapun yang menjadi sumber data penelitian ini adalah surat kabar dan majalah daring, yakni Kompas Online dan Tempo Online tahun 2008-2018. Penentuan sumber-sumber data tersebut didasari pertimbangan bahwa dalam sumber-sumber data tersebut terdapat banyak data yang menjadi objek penelitian ini. Sumber-sumber data tersebut diharapkan dapat mewakili kalimat-kalimat berstruktur predikat-subjek dengan subjek kompleks dalam bahasa Indonesia ragam jurnalistik.

\section{PEMBAHASAN}

Berikut ditampilkan data kalimat inversi dengan subjek kompleks dalam bahasa Indonesia ragam jurnalistik, beserta analisisnya. Berdasarkan penelitian terhadap data, bentuk verba yang menjadi predikatnya pada umumnya berupa verba pasif berprefiks $\{$ ter- $\}$ atau $\{\mathrm{di}-\}$. Sementara itu, subjek yang berupa subjek kompleks ini dapat berkonstruksi sebagai frasa dan dapat pula berkonstruksi sebagai klausa. Dengan demikian, pembahasan pada subbab ini diklasifikasikan atas (1) predikat verba $\{$ ter- $\}+$ subjek kompleks berkonstruksi frasa, (2) predikat verba $\{$ ter- $\}+$ subjek kompleks berkonstruksi klausa, (3) predikat verba $\left\{\mathrm{di}^{-}\right\}+$subjek kompleks berkonstruksi frasa, dan (4) predikat verba $\{$ di- $\}+$ subjek kompleks berkonstruksi klausa.

\section{Predikat Verba Berawalan \{ter- $\}$ +Subjek Kompleks Berkonstruksi Frasa}

Sebagaimana telah dikemukakan bahwa verba predikat kalimat inversi dengan subjek kompleks pada umumnya berupa verba pasif. Salah satu prefiks pasif yang sering dipakai pada kalimat jenis ini adalah prefiks $\quad$ ter- $\}$ Adapun subjek kompleksnya dapat berkonstruksi frasa dan dapat pula berkonstruksi klausa.

Berikut adalah data kalimat inversi dengan predikat verba $\{$ ter- $\}$ dan subjek kompleks berkonstruksi frasa.

(5) a. Tersiar / kabar tentang penolakan calon wakil gubernur DKI Jakarta nomor pemilihan dua, Djarot Saiful Hidayat untuk melangsungkan salat Jumat. (KO, 2017)

b. Terdengar / berita mengejutkan mengenai dibukanya kemungkinan penjualan perusahaan game Activision Blizzard. (KO, 2012)

c. Terbayang / ketidakpuasan pasien yang tidak dapat menggunakan anggota tubuhnya secara maksimal, meski telah menjalani pengobatan dan perawatan. (TO, 2012)

d. Juga, terbetik/ berita tentang keturunan Pagaruyung Minangkabau yang "terdampar" di 
pedalaman Kalimantan Tengah

(Kerajaan Kotawaringin) di sebuah negeri bernama Kudangan, yang oleh masyarakat setempat diakui sebagai leluhur mereka. (TO, 2017)

Konstituen yang dicetak miring pada contoh (5), yaitu tersiar, terdengar, terbayang, dan terbetik adalah predikat, dan konstituen yang mengikutinya adalah subjek. Pada keempat kalimat tersebut predikat ditempatkan pada awal kalimat dan baru kemudian disusul oleh subjek. Dengan demikian. struktur kalimat tersebut adalah predikat-subjek. Tampak bahwa predikat pada keempat kalimat di atas terdiri atas satu kata, yaitu verba; sedangkan subjek terdiri atas konstituen yang panjang. Subjek yang panjang pada keempat kalimat di atas berkonstruksi frasa.

Kalimat dengan susunan seperti itu, yakni diawali oleh predikat yang pendek yang terdiri atas satu atau dua kata, kemudian disusul oleh subjek yang panjang, merupakan salah satu ciri khas kalimat ragam jurnalistik. Dikatakan demikian karena kalimat-kalimat seperti itu sering muncul dalam bahasa ragam jurnalistik walaupun tidak menutup kemungkinan kalimat seperti itu dijumpai pula pada ragam yang lain.

Keempat kalimat di atas, jika dibalik susunannya menjadi subjek-predikat akan menghasilkan kalimat yang kurang lazim. Perhatikan pembalikan struktur kalimat (5) menjadi (5a) di bawah ini.

(5a) a.Kabar tentang penolakan calon wakil gubernur DKI Jakarta nomor pemilihan dua, Djarot Saiful Hidayat untuk melangsungkan salat Jumat / tersiar.

b.Berita mengejutkan mengenai dibukanya kemungkinan penjualan perusahaan game Activision Blizzard / terdengar. c. Ketidakpuasan pasien yang tidak dapat menggunakan anggota tubuhnya secara maksimal, meski telah menjalani pengobatan dan perawatan / terbayang.

d.Juga, berita tentang keturunan Pagaruyung Minangkabau yang "terdampar" di pedalaman Kalimantan Tengah (Kerajaan Kotawaringin) di sebuah negeri bernama Kudangan, yang oleh masyarakat setempat diakui sebagai leluhur mereka / terbetik.

Kalimat dengan susunan seperti contoh (5a) jarang ditemukan. Hal tersebut berbeda dengan contoh (6) di bawah. Pada contoh (6), predikat diisi oleh satuan yang berupa frasa, yakni verba + adverbia dan membentuk frasa verbal. Pembalikan struktur dari predikat-subjek pada contoh (6) menjadi subjek-predikat, yaitu pada (6a) menghasilkan struktur yang lazim. Perhatikan pembalikan struktur contoh (6) menjadi (6a) di bawah ini.

(6) a.Sempat tersiar / kabar isu perselingkuhan yang menjadi penyebab retaknya bahtera rumah tangga Nora Alexandra dan Afiff Alli yang resmi dibina pada 28 September 2016 lalu itu. (KO, 2016)

b. Terjawab sudah / teka-teki pelat nomor mobil listrik Tucuxi DI 19 yang Dikendarai Menteri Badan Usaha Milik Negara Dahlan Iskan. (TO, 2013)

c. Terjawab sudah / pertanyaan siapa yang akan mengisi kursi manajer Tottenham Hotspur. (KO, 2011)

(6a) a.Kabar isu perselingkuhan yang menjadi penyebab retaknya bahtera rumah tangga Nora Alexandra dan Afiff Alli yang resmi dibina pada 28 September 2016 lalu itu / sempat tersiar.

b. Teka-teki pelat nomor mobil listrik Tucuxi DI 19 yang Dikendarai 
Menteri Badan Usaha Milik Negara

Dahlan Iskan / terjawab sudah.

c. Pertanyaan siapa yang akan mengisi kursi manajer Tottenham Hotspur / terjawab sudah.

Predikat pada contoh (6) diisi oleh verba + adverbia dan membentuk frasa verbal: sempat tersiar dan terjawab sudah. Karena predikat diisi oleh verba + adverbia, pembalikan struktur dari predikat-subjek menjadi subjek-predikat menjadi lazim. Batas antara subjek kompleks dan predikat lebih tampak. Dengan demikian, dapat disimpulkan bahwa konstituen pengisi predikat pada kalimat inversi dengan subjek kompleks ini memengaruhi tingkat kelaziman kalimat jika kalimat tersebut dibalikkan strukturnya menjadi subjekpredikat. Jika predikat diisi oleh satuan yang berupa kata, pembalikan struktur dari predikat-subjek menjadi subjek-predikat pada umumnya menghasilkan kalimat yang kurang lazim. Namun, jika predikat diisi oleh satuan yang berupa frasa, yakni verba + adverbia, pembalikan struktur tersebut akan menghasilkan kalimat yang lazim.

\section{Predikat Verba Berawalan $\{$ ter- $\}$ +Subjek Kompleks Berkonstruksi Klausa}

Berikut adalah data kalimat inversi dengan predikat verba $\{$ ter- $\}$ dan subjek berupa subjek kompleks berkonstruksi klausa.

(7) a. Terdengar // berita bahwa pihak asuransi Sukhoi tidak mengijinkan pembentukan pansus untuk menangani asuransi bagi keluarga korban Sukhoi. (KO, 2012)

b. Tersiar // kabar bahwa calon bupati yang diusung Partai Golkar-PKS, Dedi Mulyadi, mengusulkan pemindahan lokasi pemungutan suara bagi dirinya. (KO, 2008)

c. Terdapat // bukti-bukti bahwa aktifitas fisik dapat melindungi kita dari kanker usus, yang lebih umum terjadi pada individu-individu yang berkelebihan berat badan.(TO, 2012)

d. Terbetik// kabar Maia Estianty, mantan istri musisi Ahmad Dhani, telah dilamar oleh seseorang yang identitasnya masih dirahasiakan. (TO, 2015)

Pada kalimat (7), konstituen yang dicetak miring, yaitu terdengar, tersiar, terdapat, dan terbetik adalah predikat dan konstituen yang mengikutinya adalah subjek. Seperti halnya subjek pada contoh (4) dan (5) di atas, subjek pada contoh (7) pun berupa subjek kompleks. Perbedaannya adalah subjek kompleks pada contoh (4) dan (5) berupa frasa, sedangkan subjek kompleks pada contoh (7) berupa klausa.

Sebagaimana halnya pada contoh (4), pembalikan struktur pada contoh (7) pun menghasilkan kalimat yang kurang lazim karena predikat diisi oleh konstituen yang berupa kata; sedangkan subjek berupa subjek kompleks, yang dalam hal ini berupa klausa. Perhatikan pembalikan struktur kalimat pada contoh (7) menjadi (7a) berikut ini.

(7a) a.Berita bahwa pihak asuransi Sukhoi tidak mengijinkan pembentukan pansus untuk menangani asuransi bagi keluarga korban Sukhoi // terdengar.

b. Kabar bahwa calon bupati yang diusung Partai Golkar-PKS, Dedi Mulyadi, mengusulkan pemindahan lokasi pemungutan suara bagi dirinya // tersiar.

c. Bukti-bukti bahwa aktifitas fisik dapat melindungi kita dari kanker usus, yang lebih umum terjadi pada individu-individu yang berkelebihan berat badan // terdapat.

d. Kabar Maia Estianty, mantan istri musisi Ahmad Dhani, telah dilamar oleh seseorang yang identitasnya masih dirahasiakan // terbetik.

Hal itu berbeda dengan contoh (8) berikut, yang meskipun subjeknya berupa subjek 
kompleks berkonstruksi klausa, pembalikan struktur dari predikat-subjek menjadi subjek-predikat menghasilkan kalimat yang lazim karena predikat diisi oleh konstituen yang berupa frasa, yakni verba + adverbia dan membentuk frasa verbal: terjawab sudah, pernah tercapai, dan pernah terpikir. Perhatikan pembalikan struktur pada contoh (8) menjadi (8a) di bawah ini.

(8) a. Terjawab sudah // ke mana mantan bek PSM Makassar, Hamka Hamzah, akan melanjutkan kariernya. (KO, 2018)

b. Pernah tercapai // kesepakatan bahwa hanya perwakilan buruh saja yang diizinkan ikut demo, sedangkan buruh lainnya tetap kerja. (KO, 2013)

c. Pernah terpikir // mengapa ngobrol di kafe atau restoran terasa lebih akrab dan nyaman, daripada di rumah? (KO, 2011)

(8a) a. Ke mana mantan bek PSM Makassar, Hamka Hamzah, akan melanjutkan kariernya // terjawab sudah.

b.Kesepakatan bahwa hanya perwakilan buruh saja yang diizinkan ikut demo, sedangkan buruh lainnya tetap kerja // pernah tercapai.

c.Mengapa ngobrol di kafe atau restoran terasa lebih akrab dan nyaman, daripada di rumah // pernah terpikir.

\section{Predikat Verba Berawalan $\{$ di- $\}+$ Subjek Kompleks Berkonstruksi Frasa}

Selain prefiks $\{$ ter- $\}$, prefiks pasif yang sering digunakan sebagai pembentuk verba predikat pada kalimat jenis ini adalah $\left\{\mathrm{di}^{-}\right\}$. Subjek kompleks pada verba pasif jenis ini dapat berkonstruksi frasa dan dapat pula berkonstruksi klausa.
Berikut adalah data kalimat berstruktur predikat-subjek, dengan predikat verba berprefiks $\left\{\mathrm{di}^{-}\right\}$dan subjek berupa subjek kompleks berkonstruksi frasa.

(9) a. Saat ini / diperoleh / hasil penelitian pada tahap pendahuluan yaitu berupa hasil kinerja alat pengering silinder untuk ekstrak bahan alami. (KO, 2011)

b. Setelah itu, / dikupas / berita bisnis dan keuangan, dan terakhir berita olahraga. (KO, 2010)

Kata diperoleh dan dikupas pada contoh (9) adalah predikat dan konstituen yang mengikutinya adalah subjek. Subjek kompleks yang mengikutinya berupa frasa. Sebagaimana halnya dengan verba berawalan $\{$ ter- $\}$ dan subjek kompleks berupa frasa pada contoh (4) di muka, pembalikan struktur pada contoh (9) ini pun menghasilkan kalimat yang kurang lazim. Kekuranglaziman ini pun disebabkan oleh konstituen pengisi predikat yang hanya terdiri atas verba, tanpa adverbia. Perhatikan hasil pembalikan struktur pada (9a) berikut yang kurang lazim.

(9a) a. Saat ini / hasil penelitian pada tahap pendahuluan yaitu berupa hasil kinerja alat pengering silinder untuk ekstrak bahan alami / diperoleh.

b. Setelah itu, / berita bisnis dan keuangan, dan terakhir berita olahraga / dikupas.

Hal ini berbeda dengan contoh (10) berikut, yang meskipun subjeknya berupa subjek kompleks, pembalikan struktur dari predikat-subjek menjadi subjek-predikat menghasilkan kalimat yang lazim karena predikat diisi oleh konstituen yang berupa frasa, yakni verba + adverbia dan membentuk frasa verbal. Perhatikan 
pembalikan struktur dari contoh (10) menjadi (10a) di bawah ini.

(10) a. Untuk itu / perlu dipikirkan / solusi penanganan banjir dengan memperhatikan semangat Reforma Agraria sesuai UUPA 1960. (TO, 2013)

b. Perlu diperhatikan / faktor kebersihan lingkungan, asupan makanan, ketersediaan air bersih, dan sarana mandi cuci kakus yang memadai. (KO, 2013)

c. Juga disediakan / jimat berupa tulisan dalam secarik kertas yang dikantongi saat menghadapi sidang skripsi. (TO, 2013)

(10a) a. Untuk itu / solusi penanganan banjir dengan memperhatikan semangat Reforma Agraria sesuai UUPA 1960 / perlu dipikirkan.

b. Faktor kebersihan lingkungan, asupan makanan, ketersediaan air bersih, dan sarana mandi cuci kakus yang memadai / perlu diperhatikan.

c. Jimat berupa tulisan dalam secarik kertas yang dikantongi saat menghadapi sidang skripsi / juga disediakan.

\section{Predikat Verba Berawalan $\{$ di- $\}+$ Subjek Kompleks Berkonstruksi Klausa}

Sebagaimana halnya verba predikat berawalan $\{$ ter- $\}$, predikat yang berawalan $\{\mathrm{di}-\}$ untuk jenis kalimat ini dapat diikuti oleh subjek kompleks berupa klausa. Perhatikan data pada contoh (11) berikut ini.

(11) a. Diketahui // bahwa di Titik Ukur I dan II tidak terdeteksi adanya $\mathrm{CO}$. (KO, 2013)

b. Dimohon // agar anda dapat mengisi seluruh poin pertanyaan dengan benar sesuai

dengan kondisi yang anda alami. $\mathrm{KO}, 2012$ ) c. Diketahui // bahwa di Titik Ukur I dan II tidak terdeteksi adanya $\mathrm{CO} 2$. $(\mathrm{KO}, 2013)$

Sebagaimana halnya pada contoh-contoh sebelumnya, pada contoh (11) pun kalimat diawali oleh predikat, yakni diketahui, dimohon, dan diketahui. Seperti halnya kalimat-kalimat sebelumnya pula, pembalikan struktur predikat-subjek menjadi subjek-predikat pada contoh (11), akan menghasilkan kalimat yang kurang lazim karena predikat hanya diisi oleh konstituen berupa verba, tanpa adverbia. Perhatikan hasil pembalikan struktur pada (11a) berikut ini.

(11a) a.Bahwa di Titik Ukur I dan II tidak terdeteksi adanya $\mathrm{CO} 2$ // diketahui.

b.Agar anda dapat mengisi seluruh poin pertanyaan dengan benar sesuai dengan kondisi yang anda alami // dimohon.

c.Bahwa di Titik Ukur I dan II tidak terdeteksi adanya $\mathrm{CO} 2$ // diketahui.

Kalimat seperti pada contoh (11a) jarang ditemukan. Itu sebabnya kalimat tersebut termasuk kalimat yang kurang lazim. Hal itu berbeda dengan contoh (12) berikut, yang meskipun subjeknya berupa subjek kompleks berkonstruksi klausa, pembalikan struktur dari predikat-subjek menjadi subjek-predikat menghasilkan kalimat yang lazim karena predikat diisi oleh verba + adverbia dan membentuk frasa verbal. Perhatikan pembalikan struktur contoh (12) menjadi (12a) di bawah ini.

(12) a. Perlu dipikirkan // bahwa gaji kepala daerah dihitung berdasarkan hasil prosentase dari pendapatan asli daerah (PAD) daerah yang dipimpinnya /. (KO, 2012)

b. Sulit disangkal // bahwa nama Jokowi masih menjadi 'trending 
news' media cetak dan elektronik. (KO, 2013)

c."Perlu diberitahukan // bahwa kondisi terakhir telah disampaikan ke keluarga yang bersangkutan dan kuasa hukum," kata dia. (TO, 2017)

(12a) a. Bahwa gaji kepala daerah dihitung berdasarkan hasil prosentase dari pendapatan asli daerah (PAD) daerah yang dipimpinnya // perlu dipikirkan.

b. Bahwa nama Jokowi masih menjadi 'trending news' media cetak dan elektronik // sulit disangkal.

c. "Bahwa kondisi terkahir telah disampaikan ke keluarga yang bersangkutan dan kuasa hukum," kata dia // perlu diberitahukan.

Tampak bahwa pembalikan struktur dari predikat-subjek pada contoh (12) menjadi subjek-predikat pada (12a) menghasilkan kalimat yang lazim karena predikat diisi oleh verba + adverbia.

Berdasarkan contoh-contoh dan analisis yang telah dikemukakan dapat disimpulkan bahwa pembalikan struktur dari predikat-subjek menjadi subjekpredikat pada kalimat inversi dengan subjek kompleks bergantung pada konstituen pengisi predikat. Jika predikat berupa verba saja, pembalikan struktur akan menghasilkan kalimat yang kurang lazim. Namun, jika predikat berupa verba + adverbia sehingga membentuk frasa verbal, pembalikan struktur akan menghasilkan kalimat yang lazim.

\section{PENUTUP}

Berdasarkan uraian yang telah dikemukakan dapat disimpulkan hal-hal sebagai berikut.

1. Dalam bahasa Indonesia ragam jurnalistik banyak ditemukan kalimat inversi dengan subjek kompleks. Subjek kompleks ini, berdasarkan konstruksinya, dapat berupa frasa dan dapat pula berupa klausa. Adapun predikatnya ada yang berupa kata, yakni verba saja, dan ada pula yang berupa frasa, yakni verba + adverbia dan membentuk frasa verbal. Bentuk verba predikatnya pada umumnya berupa verba pasif berawalan $\{$ ter- $\}$ atau $\left\{\mathrm{di}^{-}\right\}$.

2. Perubahan atau pembalikan struktur dari predikat-subjek menjadi subjek-predikat pada kalimat inversi dengan subjek kompleks ini pada umumnya bergantung pada konstituen pengisi predikat. Jika predikat berupa verba saja, pembalikan struktur dari predikatsubjek menjadi subjek-predikat akan menghasilkan kalimat yang kurang lazim. Namun, jika predikat berupa verba + adverbia sehingga membentuk frasa verbal, pembalikan struktur dari predikat-subjek menjadi subjek-predikat akan menghasilkan kalimat yang lazim. Hal tersebut berlaku baik untuk predikat berprefiks $\{$ ter- $\}$ maupun $\{$ di- $\}$. Hal itu berlaku pula baik untuk subjek kompleks berkonstruksi frasa maupun subjek kompleks berkonstruksi klausa.

\section{DAFTAR PUSTAKA}

Alwi, H., Dardjowidjojo, S., Lapoliwa, H., \& Moeliono, A. M. (2003). Tata Bahasa Baku Bahasa Indonesia (Edisi Ketiga). Jakarta: Balai Pustaka.

Chomsky, Noam. (1965). Aspects of the Theory of Syntax. Cambridge, Mass.: The MIT Press.

Djajasudarma, T. F. (1993). Metode Linguistik. Bandung: PT Eresco.

Halim, Amran. (1984). Intonasi dalam Hubungannya dengan Sintaksis Bahasa Indonesia. Jakarta: Djambatan.

Kaswanti Purwo, Bambang dan Anton M. Moeliono. (1985). Analisis Fungsi Subjek dan Objek: Sebuah Tinjauan. Dalam Kaswanti Purwo (Ed.). 
Untaian Teori Sintaksis 1970-1980 an. Jakarta: Arcan.

Kaswanti Purwo, Bambang. (1985). Inversion in Indonesian Narratives: Syntax and Discourse. Fourth Conference on Austronesian Language. University of Michigan, Ann Arbor, 1-3 Agustus 1985.

Kaswanti Purwo, Bambang. (1987). Subjek-Predikat dan Topik-Komen: Liku-Liku Perkembangannya. Konferensi Nasional Kelima Masyarakat Linguistik Indonesia. Ujung Pandang, 22-27 Juli 1987.

Kaswanti Purwo, Bambang. (1989). Pola Urutan SV/VS dan Perubahan Struktur Sintaktis Bahasa Indonesia. Atma nan Jaya. Majalah Ilmiah Universitas Katolik Indonesia Atma Jaya. Juni 1989.

Kaswanti Purwo, Bambang. (2009). Tipologi Bahasa: Pengantar. Dalam Panorama Pengkajian Bahasa, Sastra, dan Pengajarannya. Program Pascasarjana Fakultas Sastra dan Seni Rupa Universitas Sebelas Maret

Lyons, John. (1968). Introduction of Theoretical Linguistics. Cambridge: Cambridge University Press.
Quirk, Randolph, et.al. (1985). A Comprehensive Grammar of the English Language. London: Longman Sudaryanto. (1992). Metode Lingustik. Yogyakarta: Fakultas Sastra dan Kebudayaan Universitas Gadjah Mada.

Sudaryanto. (1993). Metode dan Aneka Teknik Analisis Bahasa. Yogyakarya: Duta Wacana University Press.

Sudaryanto. (1994). Predikat-Objek dalam Bahasa Indonesia: Keselarasan Pola Urutan. Jakarta: Djambatan.

Sugono, Dendy dan Titik Indiyastini. (1994). Verba dan Komplementasinya. Jakarta: Pusat Pembinaan dan Pengembangan Bahasa.

Tjung, Yassir. (2003). On AdaConstructions in Indonesian. Dalam Katharina Endriati Sukamto (Ed.). Cakrawala Baru. Jakarta: Yayasan Obor Indonesia 